\title{
STUDY OF THE MORPHOLOGICAL AND ANATOMIC SIGNS OF THE FLOWERS OF THE CHRYSANTHEMUM HORTORUM BAILEY SORT PECTORAL (PHARMACOGNOSTIC ANALYSIS)
}

\section{S. Marchyshyn, O. Polonets, M. Harnyk, L. Sira}

The aim. To study of the morphological and anatomical features of the structure of inflorescences of Chrysanthemum $\times$ hortorum Bailey, variety Pectoral.

Materials and methods. The inflorescences of Chrysanthemum $\times$ hortorum Bailey, cultivar Pectoral were used for the analysis. The raw materials were harvested in the phase of mass flowering of plants in SeptemberOctober 2019 at the experimental plots of the department of floral and ornamental plants of the National Botanical Garden named after M.M. Grishko of the National Academy of Sciences of Ukraine in Kyiv.

Results. The investigated inflorescences are represented by bright orange double baskets, consisting of seated semiflorets and disk flowers arranged spirally on a convex bare anthoclinium. The involucrum of Chrysanthemum $\times$ hortorum Bailey inflorescences of the Pectoral variety has a dense structure with elongated leathery leaves. The marginal flowers of the anthodium are red-orange, pseudo-ligate female; the middle flowers are yellow, tubular, bisexual. The apex and edge of the epidermal cells of pseudo-ligate flowers are characterized by papillary growth and slight folding of the cuticle; at the base of the corolla lingula there are cells with calcium oxalate crystals in the form of small druses. The anatomical structure of tubular flowers is characterized by essential oil glands, typical for the Asteraceae family. The epidermis of the wrapper leaves is represented by oval cells with numerous essential oil glands and large surface outgrowths.

Conclusions. The main diagnostic morphological and anatomical features of the inflorescences of Chrysanthemum $\times$ hortorum Bailey cultivar Pectoral have been established, which can be further used in the identification of new medicinal plant materials

Keywords: morphological structure, anatomical structure, inflorescences, Chrysanthemum $\times$ hortorum Bailey, cultivar Pectoral

Copyright (C) 2020, S. Marchyshyn, O. Polonets, M. Harnyk,. $\quad$ L. Sira This is an open access article under the CC BY license (http://creativecommons.org/licenses/by/4.0).

\section{Introduction}

The genus Chrysanthemum is represented by annual and perennial species, of which there are many in the world flora [1, 2]. Plants of the Chrysanthemum genus are common in northern, temperate and subtropical latitudes of the globe [3]. Garden chrysanthemums are divided into subgroups, sections, varieties, individual forms (herbaceous, shrub or semi-shrub). In addition, there are open and closed chrysanthemums [4].

Today there are more than 10,000 different varieties of chrysanthemums in the world [5]. Thus in different countries selection has the features. For example, in America the most popular varieties with anemone inflorescences, in Germany and Great Britain - with spherical and hemispherical, in Japan and China - with the original arachnoid and radiant inflorescences. In Europe, many chrysanthemums have long been grown in pots, while in Ukraine this trend has come relatively recently. And in North America, Great Britain and the Netherlands, most products are used for sale [3].

Representatives of the Chrysanthemum genus have a more or less branched rhizome, which forms stolon-shaped underground shoots. Stem annual, erect, branched, pubescent, semi-woody, brittle, from 25 to $150 \mathrm{~cm}$ tall, usually dark green, sometimes light green with a smoky tinge $[5,6]$. Shrubs of various shapes (spherical, cone-shaped, etc.), depending on the nature of branching and growing conditions $[4,5]$. Leaves alternate, simple or pinnately dissected, with stipules, the upper side is green, sometimes pubescent, the lower greyish-green, pubescent. Stem leaves of small-flowered varieties up to $7 \mathrm{~cm}$ long and up to $4 \mathrm{~cm}$ wide, largeflowered -15 and $8 \mathrm{~cm}$, respectively. Well-marked speckled glands emit a characteristic odor of camphor $[5,7,8]$.

The expanded and thickened apex of the flowering stem, surrounded by an involucrum of numerous narrow green leaves, forms a perianth on which is located an anthodium of peripheral unisexual ligulate flowers, forming a variety of brightly colored corollas. Bisexual tubular flowers are located in the center of the bed. Terry inflorescences are caused by variations of internal tubular flowers in the ligulate [4-8].

Chrysanthemums are characterized by seven main colors of inflorescences: white, cream, red, bronze, green and many transitional shades. There are two-color inflorescences, then take into account the color of the outer and inner sides of the petals [7,8].

The size of anthodium in small-flowered varieties $2-6 \mathrm{~cm}$ in diameter, the inflorescences are collected in a raceme.

In large-flowered anthodium size $10-15 \mathrm{~cm}$, sometimes up to $35 \mathrm{~cm}$, the inflorescences are single or in clusters of 2-10 on one shoot [5-9]. 
The perennial garden chrysanthemum species (Chrysanthemum $\times$ hortorum Bailey) is popular in garden and park landscaping and belongs to the autumnflowering ornamental plants [2, 3, 10]. In addition, chrysanthemum is known in folk medicine of the East as an antipyretic, analgesic, anti-inflammatory and tonic agent $[2,11,12]$.

\section{Research planning (methodology)}

The search for new sources of medicinal plant raw materials, improving the technology of drug production, as well as a comprehensive approach to the use of pharmacopoeial species of medicinal plants is a topical issue in the modern pharmaceutical industry [13]. In this regard, members of the family Asteraceae, in particular flower and ornamental species, such as various varieties of the genus Chrysanthemum, are of great scientific interest and industrial importance $[14,15]$.

Preliminary studies of the chemical composition suggest that the raw material of chrysanthemums is rich in different classes of biologically active substances [2]. The leaves and flowers of Chrysanthemum $\times$ hortorum Bailey contain significant amounts of polysaccharides, fatty and organic acids, essential oil, carotenoids, chlorophylls, phenolic compounds (tannins, flavonoids, coumarins, hydroxycinnamic acids), amino acids and micro acids. their pharmacological activity with the prospect of its widespread use in medical practice [1, 2, 16-19].

Therefore, the study of the morphological and anatomical structure of terrestrial and subterranean plant organs is an integral stage of standardization in the study of medicinal plant raw materials. It was important to establish macroscopic and microscopic diagnostic features of the raw material Chrysanthemum $\times$ hortorum
Bailey of the Pectoral variety, as this information is not presented in the available literature sources.

\section{Materials and methods}

The objects of the study were perennial garden chrysanthemum inflorescences (Chrysanthemum $\times$ hortorum Bailey). Raw materials were harvested in the phase of mass flowering of plants in September-October 2019 at the research sites of the Department of flower and ornamental plants of the National Botanical Garden named after M. M. Grishko of the National Academy of Sciences of Ukraine in Kyiv.

The raw materials were dried in the shade under tents. Spread a thin layer $(2-3 \mathrm{~cm})$ on paper and periodically flipped. The dried raw materials were packed in cloth bags and stored in a dry, protected from direct sunlight, cool room.

A magnifying glass and a binocular microscope "Granum" were used to study the morphological structure of the raw material. The anatomical structure of the flowers of the studied species was studied according to the generally accepted pharmacopoeial methods of microscopic analysis described in the monographs of SPhU [20-24]. Diagnostic microscopic signs were recorded using a microscope "Granum" at a magnification of $\times 40$, $\times 100, \times 400$ times. The photos were taken with a Sony DSC-W80 camera.

\section{Research results}

The studied inflorescences are bright densely terry anthodium, consisting of a large number of sessile ligulate and tubular flowers on a convex, arranged in a spiral on a bare anthoclinium. The inflorescence wrapper is dense, formed by tile-like modified leathery leaves of oblong-oval shape with a membranous border (Fig. 1).

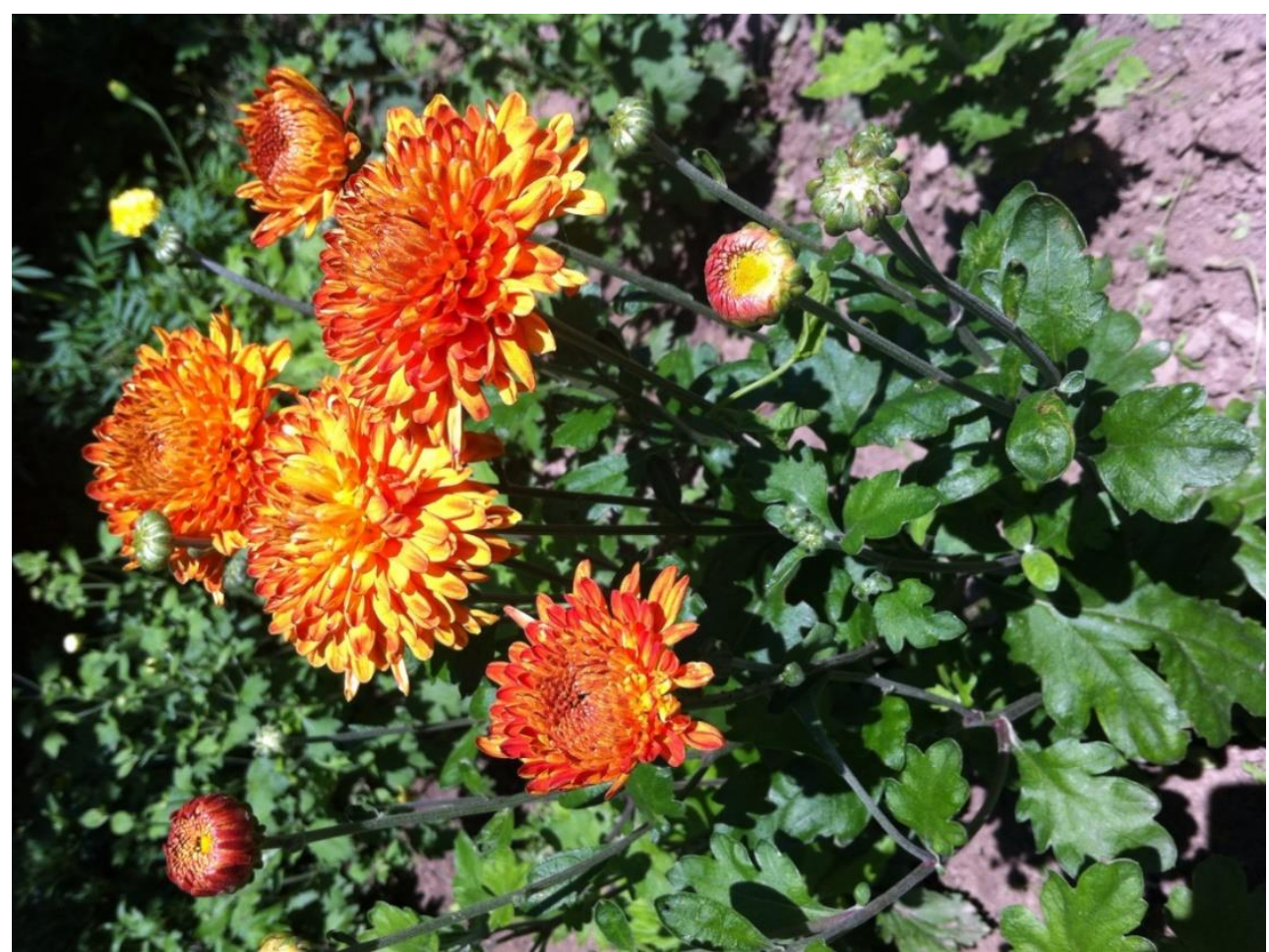

Fig. 1. Chrysanthemum $\times$ hortorum Bailey, Pectoral variety 
Along the edge of the anthodium are red-orange zygomorphic false-tongued female flowers. Their corolla of the lingual type has only one tooth (Fig. 2), which is due to the full growth of the five petals.

The middle flowers of anthodium are yellow, bisexual, with fused pentamerous tubular corolla. The column changes its length: first it is shorter, and then longer than the corolla tube. Stigma bilobed, lower ova- ry. Anthers of five stamens grow into a tube around the column. They have four pollen nests, open by a slit inside the tube. Pollen ripens earlier than the stigma (dichogamy). Achene without a fly.

The anatomical structure of the false-lingual flower is presented in Fig. 3. In Fig. 4, 5 the microscopic features of the tubular flower are shown, in Fig. 6 leaves wrapper anthodium.
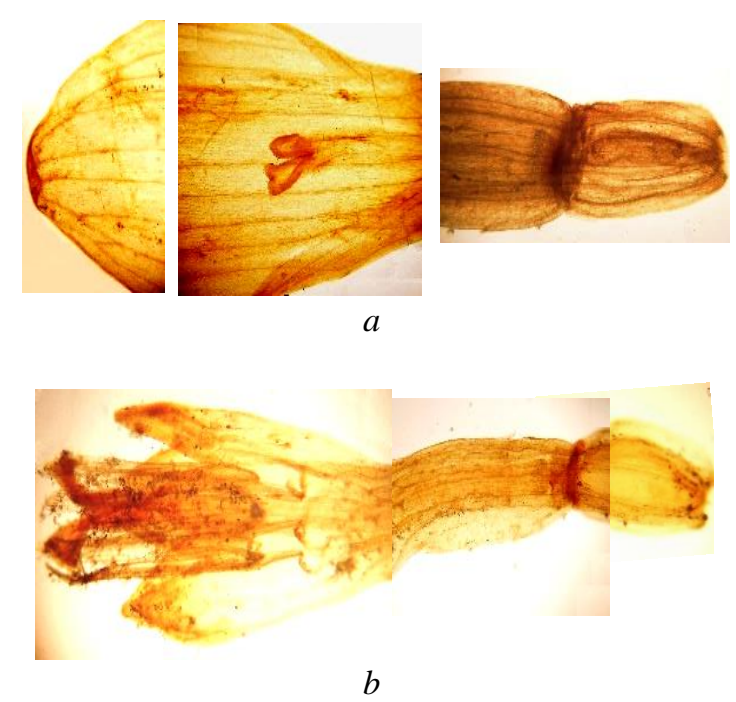

Fig. 2. Fragments of Chrysanthemum $\times$ hortorum Bailey flowers of Pectoral variety: $a$ - false-ligulate flower; $b$ - tubular flower
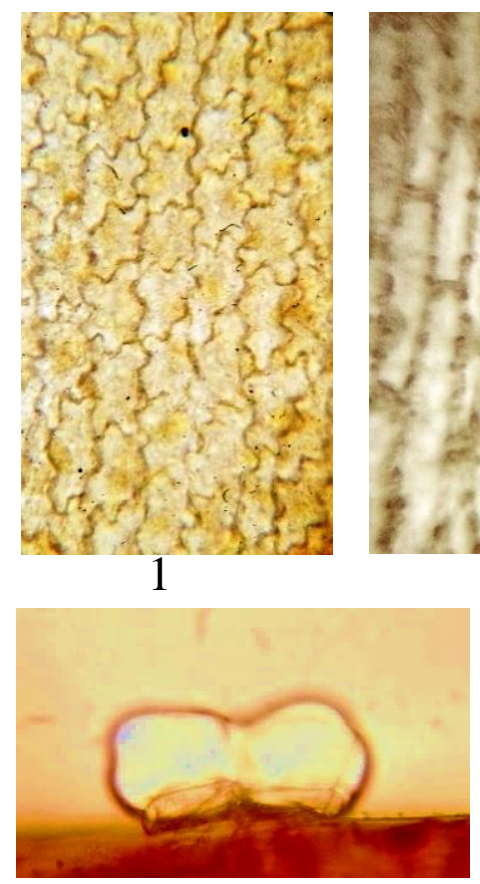

4

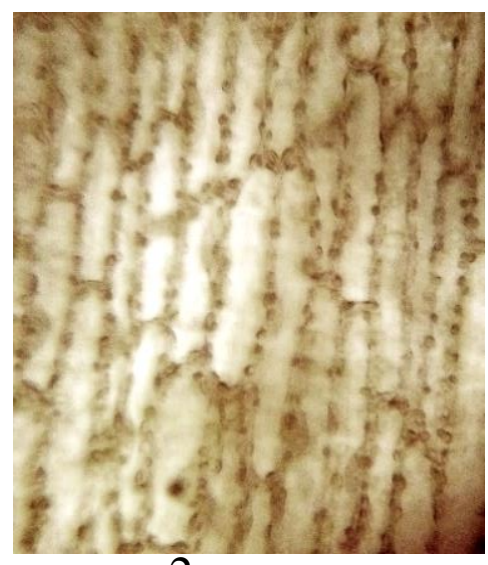

2

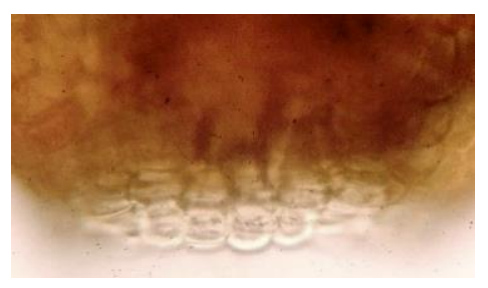

5

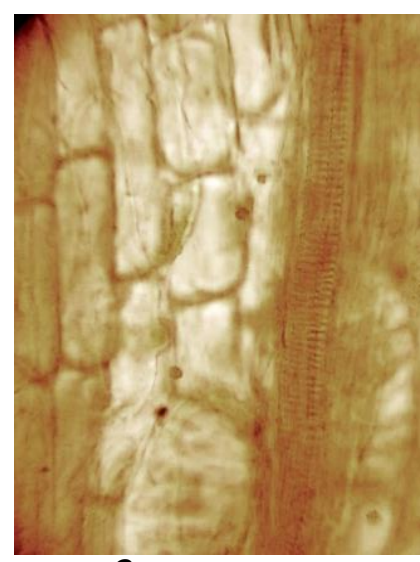

3

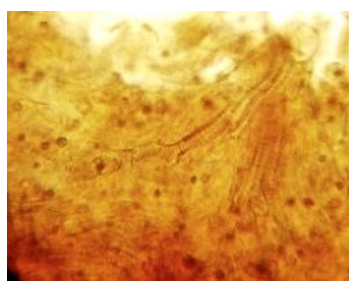

6

Fig. 3. Fragments of superficial preparations of false ligulate flowers: 1 - epidermis of the upper part of the tongue; 2 - epidermis of the middle part of the tongue; 3 - veins and epidermis near them; 4 - essential oil glands; 5 - basic part of the flower; 6 - cells with small druses 

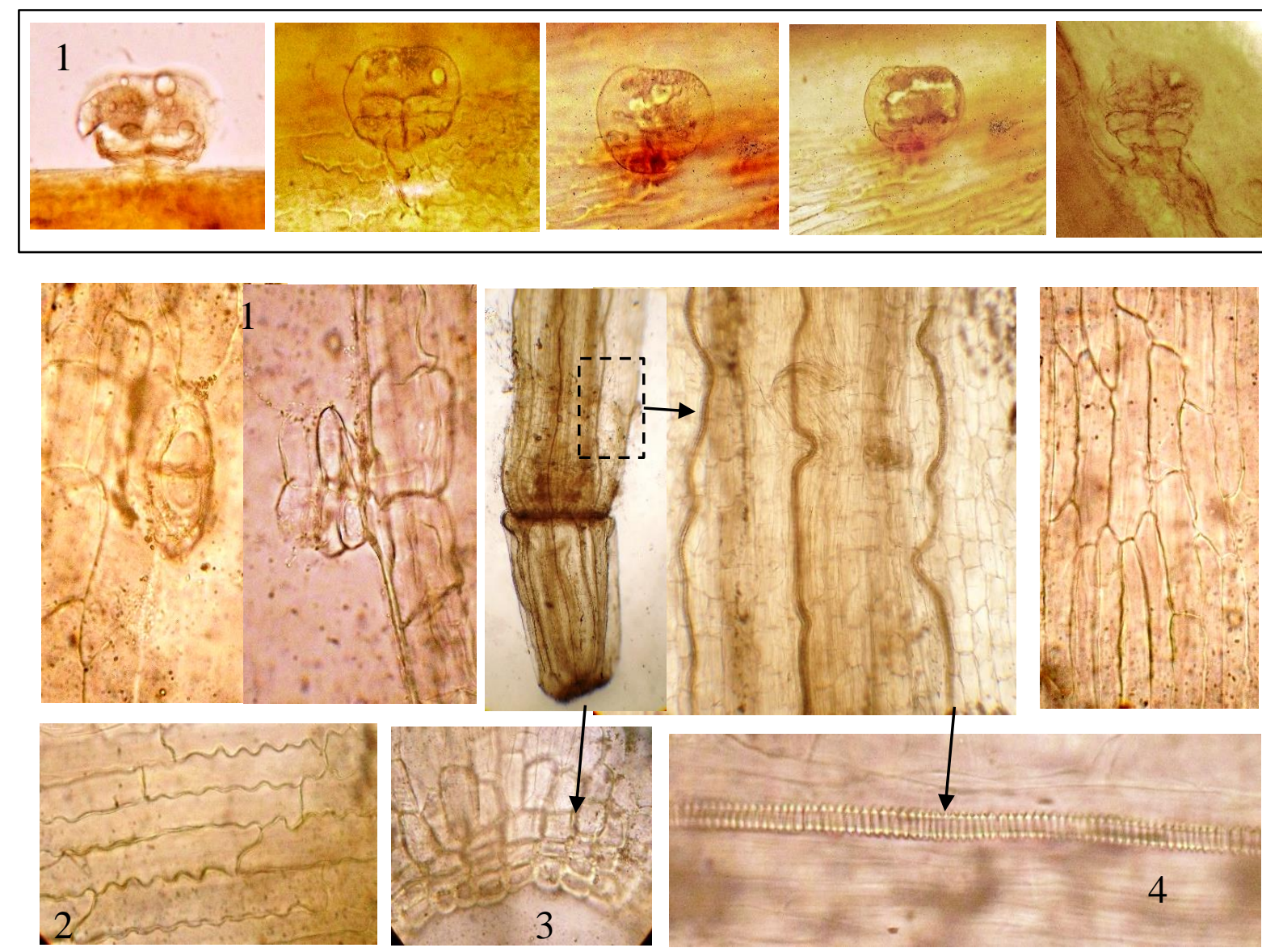

Fig. 4. Fragments of surface preparations of the tube of middle flowers: 1 - essential oil glands; 2 - epidermis of the tube; 3 - sclerified cells of the basal part of the flower; 4 - spiral vessel of the vein
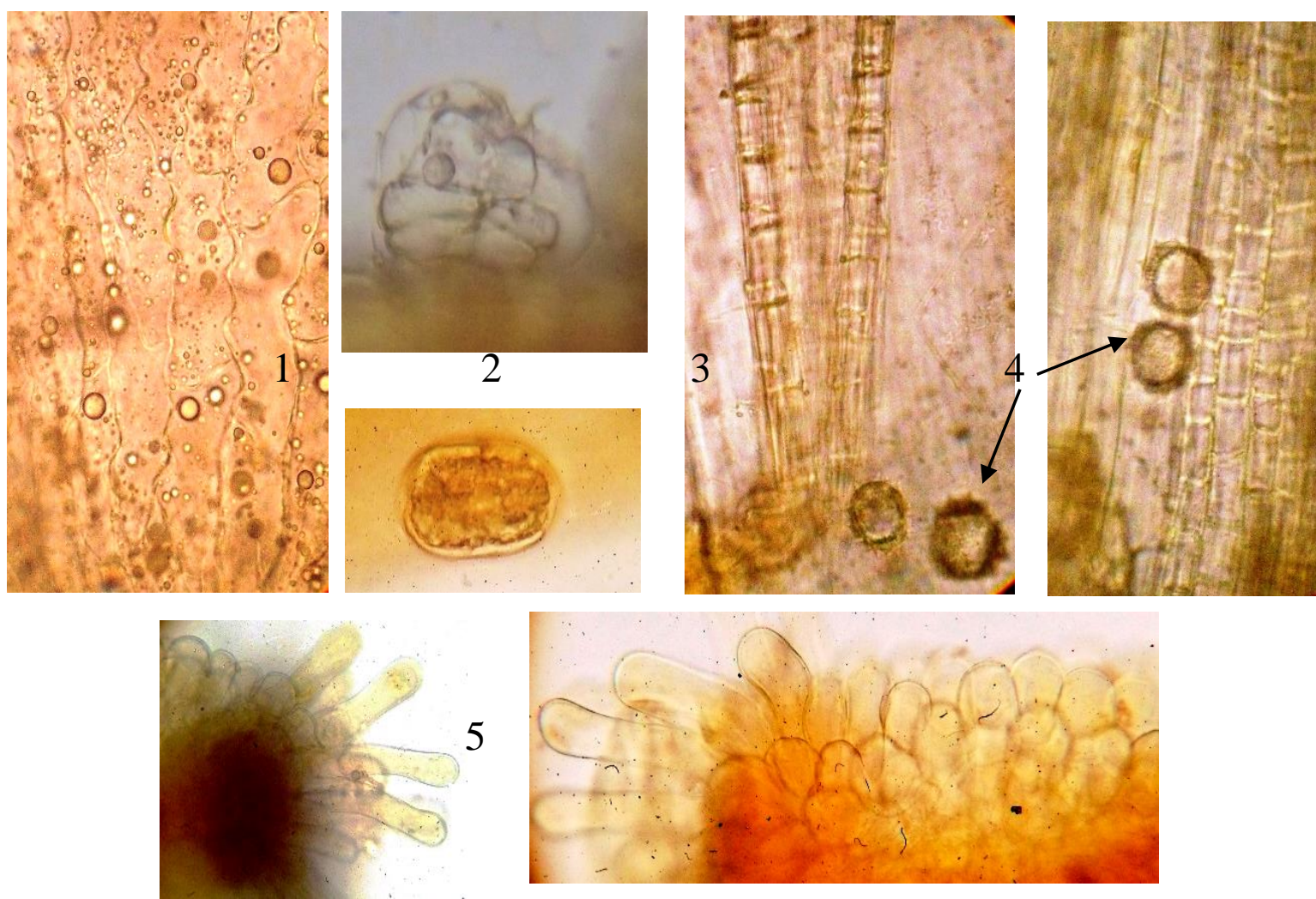

Fig. 5. Fragments of surface preparations of tubular flowers: 1 - epidermis of the limb; 2 - essential oil glands (side and top view); 3 - stamen filament; 4 - pollen grains; 5 - outgrowths of pistil style cells 

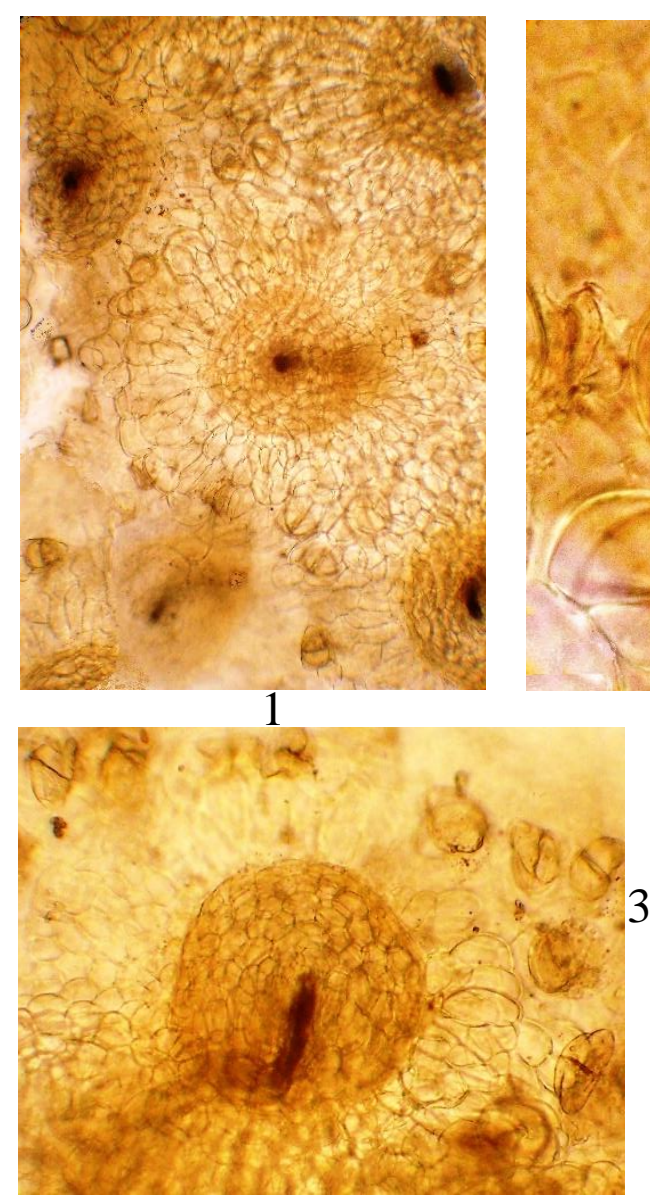

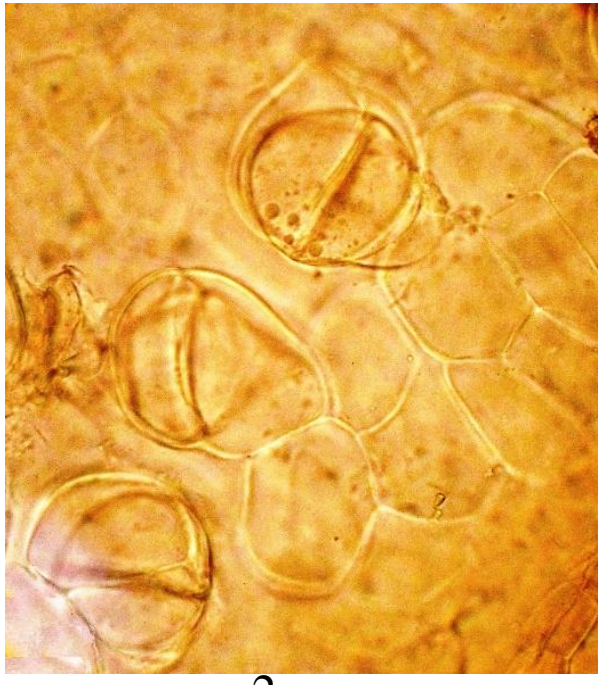

2

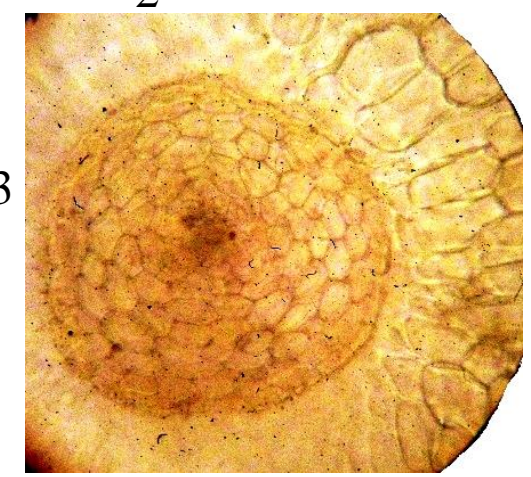

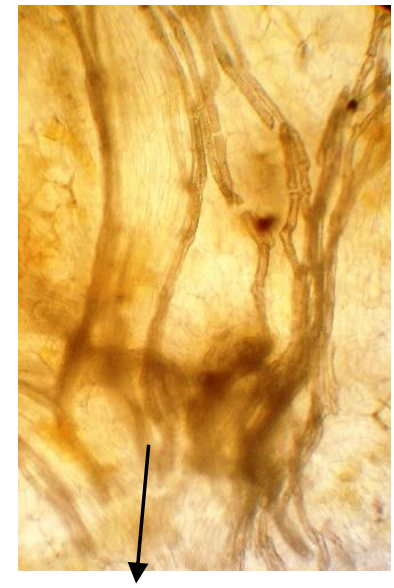

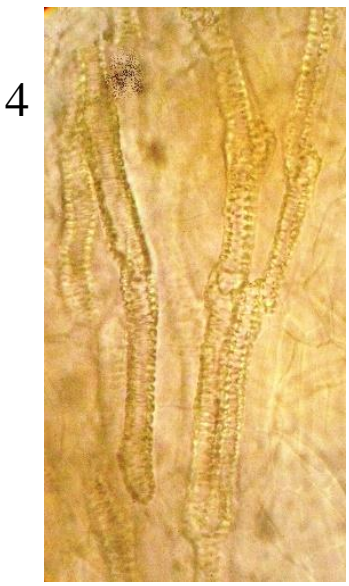

Fig. 6. Fragments of surface preparations of anthodium wrapper leaves: 1 - general view of the upper epidermis; 2 - epidermis with essential oil glands; 3 - multicellular emergencies; 4 - veins

\section{Discussion}

In world scientific sources there is a tendency to study different species of chrysanthemums in terms of selection of new ornamental varieties for economic purposes [3-6] or in terms of karyomorphological analysis [7-9]. We carried out an original morphological and anatomical study of diagnostic signs of raw materials of one of the domestic varieties of chrysanthemums. Analysis of literature data and electronic information resources does not contain data for comparison.

The epidermis of the upper part of the lingual corolla without stomata, the basal cells between the thin veins are slightly elongated, tortuous, more or less papillary (Fig. 3.1). In the middle part of the epidermis, the cells are more elongated, porous, and have thickened membranes (Fig. 3.2). Closer to the veins and over them are dominated by rectangular cells. Veins often consist of one or two thin vessels with spiral thickenings (Fig. 3.3). Occasionally there are essential oil glands with a large oval 8-cell head (Fig. 3.4). At the base of the flower (Fig. 3.5), which is attached to the anthoclinium of anthodium, the cells are rectangular, have a thickened lignified shell. The cells at the border of the corolla and ovary contain small drusen (Fig. 3.6).

The middle flowers of anthodium have a tubular corolla with an epidermis rich in essential oil glands, the structure of which is typical for most species of aster. They are large, oval, more abundant in the epidermis of the tube (Fig. 4.1).
The cells of the epidermis covering the tube are elongated, their walls are thin, straight, or tortuous (Fig. 4.2). Like marginal flowers, the basal part of the flower is strengthened by 2-3 layers of sclerified cells (Fig. 4.3). Vessels of veins are thin, spiral (Fig. 4.4).

The cells of the epidermis of the limb (Fig. 5.1) are large, elongated, tortuous, with papillary growths, especially on the teeth. The glands often have an elevated cuticle, under which is the essential oil (Fig. 5.2). Stamen filaments (Fig. 5.3) consist of a columnar row of rectangular thickened cells attached to the inner surface of the corolla. Large anthers contain spherical pollen grains (Fig. 5.4) with a prickly surface. The snout of pistil is hairy, the growths of epidermal cells are thin-walled, of different lengths, wide, rounded at the apex, colourless (Fig. 5.5).

The structure of the leaves that make up the wrapper is specific (Fig. 6). The epidermis consists of parenchymal round cells (Fig. 6.1), a large number of essential oil glands (Fig. 6.2) and large emergencies, which occupy a significant area. Emergent spherical, have a multicellular and multilayered stand surrounded by a multicellular rosette (Fig. 6.3). The leading system of leaves is well developed, branched. The veins are dominated by porous vessels (Fig. 6.4).

Study limitations. The microscopic method of analysis is highly reliable in the identification of medicinal plant raw materials, but a characteristic diagnostic feature of the predominant larger members of the family 
Asteraceae is the presence of typical essential oil glands, which can cause difficulties in diagnosing raw materials Chrysanthemum $\times$ hortorum Bailey of the Pectoral variety according to this diagnostic feature.

Prospects for further research. The prospect of further research is to continue the pharmacognostic study of plants of the Chrysanthemum genus to develop draft methods of quality control for new medicinal raw materials "Chrysanthemum $\times$ hortorum Bailey flower".

\section{Conclusions}

The main diagnostic morphological and anatomical features of Chrysanthemum $\times$ hortorum Bailey flowers of Pectoral variety have been established.

Morphological features of anthodium inflorescences have a slightly convex, tuberous-pitted, bare common anthoclinium, fortified with a dense leaf wrapper of oval-cylindrical leaves, tiled.

On a anthoclinium on a spiral sessile flowers are placed. The main mass consists of false-tongued female flowers, the tongue of which has two, rarely three indistinct teeth or one-toothed. The middle flowers are small, bisexual, with a tubular yellow corolla. The leaves of the wrapper on the edge of the film.
Anatomical features of flowers characterize the peculiarities of the structure of the epidermis of ligulate and tubular flowers, as well as the leaves of the wrapper. Epidermis of false ligulate flowers without stomata, occasionally essential oil glands. The cells of the upper part are slightly elongated, tortuous, the middle part more elongated, porous, have thickened shells, at the base - rounded with thickened lignified shells. Cells on the border of the tongue and corolla contain small drusen. A characteristic feature of the epidermis of tubular flowers is the presence of a large number of essential oil glands. The cells covering the tube are elongated, thin-walled, more or less tortuous. The cells of the epidermis of the limb - with papillary growths, which are especially abundant on the teeth. The epidermis of the leaves of the wrapper consists of rounded cells, a large number of essential oil glands and spherical emergencies.

The established macroscopic and microscopic features of Chrysanthemum $\times$ hortorum Bailey flowers of Pectoral variety can be further used in the identification of new medicinal plant raw materials.

\section{Conflict of interests}

There is no conflict of interests according to this study.

\section{References}

1. Demydiak, O. L. (2014). Vmist zhyrnykh ta orhanichnykh kyslot u kvitkakh i lystkakh khryzantemy sadovoi bahatorichnoi. Farmatsevtychnyi chasopys, 3, 27-31.

2. Marchyshyn, S. M., Harnyk, M. S., Polonets, O. V., Ambok, Kh. Yu. (2020). Dosvid vykorystannia dekoratyvnykh roslyn u medychnii praktytsi (ohliad literatury) Perspektyvni napriamky naukovykh doslidzhen likarskykh ta efirooliinykh kultur, $219-225$.

3. Trautwein, K. S., Klemeshova, K. V. (1970). The history of studying chrysanthemum (Chrysanthemum $\times$ hortorum Bailey) in the Russian Research Institute of Floriculture and Subtropical Crops. Subtropical and Ornamental Horticulture, 64, $26-33$. doi: http://doi.org/10.31360/2225-3068-1970-64-26-33

4. Antonova, K. S., Klemeshova, K. V. (2017). Kultura Chrysanthemum $\times$ hortorum Bailey vo Vserossiiskom nauchnoissledovatelskom institute tsvetovodstva i subtropicheskikh kultur i perspektivy ee izucheniia. Plodovodstvo i iagodovodstvo, 51, 121-129.

5. Novye sorta khrizantemy vo vlazhnykh subtropikakh Chernomorskogo poberezhia Krasnodarskogo kraia. Subtropicheskoe i dekorativnoe sadovodstvo. (2016). Sochi: VNIITSiSK, 90-94.

6. Kozmenko, N. P. (2015). Melkotsvetnye khrizantemy. Novinki dlia subtropicheskoi zony Rossii. Tsvetovodstvo, 1, 12-15.

7. Ivanova, V. (1998). Morphological Characteristics of Chrysanthemum Plants, One-; Two-Or Three Stem Formated. Progress in Botanical Research, 313-316. doi: http://doi.org/10.1007/978-94-011-5274-7_71

8. Hoang, T. K., Wang, Y., Hwang, Y.-J., Lim, J.-H. (2020). Analysis of the morphological characteristics and karyomorphology of wild Chrysanthemum species in Korea. Horticulture, Environment, and Biotechnology, 61 (2), 359-369. doi: http://doi.org/10.1007/s13580-019-00222-9

9. Gao, K., Song, X., Kong, D., Dai, S. (2020). Genetic Analysis of Leaf Traits in Small-Flower Chrysanthemum (Chrysanthemum $\times$ morifolium Ramat.). Agronomy, 10 (5), 697. doi: http://doi.org/10.3390/agronomy10050697

10. Burmistrova, N. O., Fabryka, M. R. (2020). Chrysanthemum coronarium L. v kolektsii Natsionalnoho dendrolohichnoho parku «Sofiivka» NAN Ukrainy, Perspektyvni napriamky naukovykh doslidzhen likarskykh ta efirooliinykh kultur, 21-23.

11. Chinese Pharmacopoeia Commission (2010). Pharmacopoeia of the people's Republic of China, 292.

12. Duke, J. A. (2002). Handbook of medicinal herbs. CRC PRESS, 193-194.

13. Sambukova, T. V., Ovchinnikov, B. V., Ganapol'sky, V. P., Yatmanov, A. N., Shabanov, P. D. (2017). Prospects for phytopreparations (botanicals) use in modern pharmacology. Reviews on Clinical Pharmacology and Drug Therapy, 15 (2), 56-63. doi: http://doi.org/10.17816/rcf15256-63

14. Marchishin, S. M., Demidiak, O. L., Dakhim, I. S., Berdei, T. S., Kozir, G. R. (2015). Research of polysaccharide complexes from asteraceae family plants. ScienceRise, 10 (4 (15)), 31-36. doi: http://doi.org/10.15587/2313-8416.2015.52002

15. Polonets, O. V. Marchyshyn, S. M., Sira, L. M., Demydiak, O. L. (2018). Morphological and anatomical characteristics of leaves of chrysanthemum garden perennial varieties Belgo and Pectoral. Pharmaceutical review, 2, 17-22.

16. Marchyshyn, S., Polonets, O., Zarichanska, O., Garnyk, M. (2017). GS/MS analysis of fatty acids in flowers and leaves of Chrysanthemum $\times$ hortorum Bailey Belgo and Pectoral' variants. The Pharma Innovation International Journal, 6 (11), $463-466$.

17. Marchyshyn, S. M., Polonets, O. V., Garnyk, M. S., Zarichanska, O. V. (2019). Volatile compounds of garden chysanthemum (Chrysanthemum $\times$ hortorum bailey) variant pectoral. Fitoterapia, 3 (3), 38-42. doi: http://doi.org/10.33617/25229680-2019-3-38

18. Marchyshyn, S. M., Demydiak, O. L., Polonets, O. V., Harnyk, M. S. (2016). Doslidzhennia fenolnykh spoluk khryzantemy sadovoi bahatorichnoi (Chrysanthemum $\times$ hortorum Bailey). Medychna ta klinichna khimiia, 18 (2), 48-53. 
19. Marchyshyn, S. M., Polonets, O. V., Harnyk, M. S., Demydiak, O. L. (2017). Elementnyi sklad kvitok ta lystkiv khryzantemy sadovoi bahatorichnoi (Chrysanthemum $\times$ hortorum Bailey). Ukrainskyi biofarmatsevtychnyi zhurnal, 5 (52), 46-49.

20. Derzhavna farmakopeia Ukrainy. Vol. 3 (2014). Kharkiv: Derzhavne pidpryiemstvo Ukrainskyi naukovyi farmakopeinyi tsent yakosti likarskykh zasobiv, 724 .

21. Derzhavna farmakopeia Ukrainy. Vol. 1 (2015). Kharkiv: Derzhavne pidpryiemstvo Ukrainskyi naukovyi farmakopeinyi tsent yakosti likarskykh zasobiv, 1126.

22. Furst, G. P. (1979). Metody anatomo-gistokhimicheskogo issledovaniia rastitelnykh tkanei. Moscow: Nauka, 154.

23. Serbin, A. G., Kartamazova, L. S., Rudenko, V. P., Gontovaia, T. N. (2006). Atlas po anatomii rastenii. Kharkiv: Kolorit, 86. Press, 284.

24. Hajibagheri, N. (2003). Electron Microscopy. Methods and Protocols. Methods In Molecular Biology. Totowa: Humana

25. Gao, K., Song, X., Kong, D., Dai, S. (2020). Genetic Analysis of Leaf Traits in Small-Flower Chrysanthemum (Chrysanthemum $\times$ morifolium Ramat.). Agronomy, 10 (5), 697. doi: http://doi.org/10.3390/agronomy10050697

Received date 17.06.2020

Accepted date 15.07.2020

Published date 31.08.2020

Svitlana Marchyshyn, Doctor of Pharmaceutical Sciences, Professor, Department of Pharnacognosy with Medical Botany, Ivan Horbachevsky Ternopil National Medical University Ministry of Health of Ukraine, Voli ave., 1, Ternopil, Ukraine, 46001

E-mail: svitlanafarm@ukr.net

Olha Polonets, Assistant, Department of Pharmaceutical Chemistry, National Pirogov Memorial Medical University, Pirogova str., 56. Vinnitsya, Ukraine, 21018

E-mail: olghapolonets@gmail.com

Myroslava Harnyk, PhD, Associate Professor, Department of Pharmaceutical Chemistry, National Pirogov Memorial Medical University, Pirogova str., 56. Vinnitsya, Ukraine, 21018

E-mail: svlava-garnyk@ukr.net 